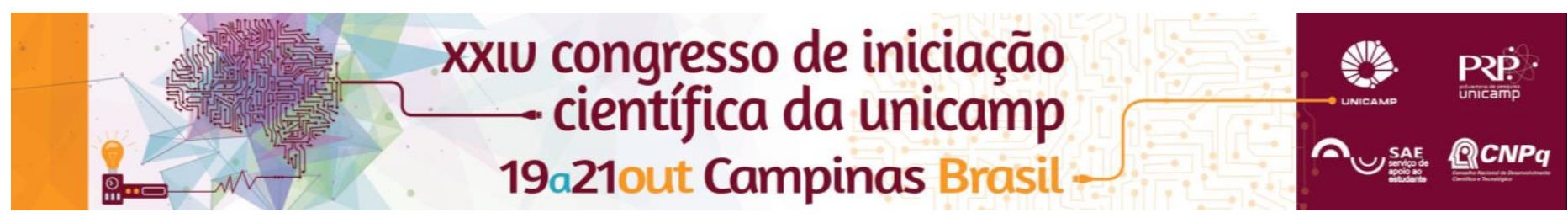

\title{
Relações de idade na Educação Infantil. As culturas infantis em meio à sociedade adultocêntrica predominante.
}

Tatiana Renzo Fonseca.

\begin{abstract}
Resumo
Esta pesquisa consistiu em aprofundar o estudo das relações de idade na Educação Infantil, dando continuidade à pesquisa realizada no campo das Ciências Sociais e iniciada em 2014 por meio de financiamento do PIBIC/CNPq. Na primeira parte da pesquisa foi feita a análise da importância da convivência entre crianças pequenas de diferentes idades da pré-escola em uma instituição pública de Educação Infantil da cidade de Campinas/SP, por meio da etnografia. Os registros oriundos desse estudo apresentaram inúmeros elementos que foram aprofundados nesta nova fase, como as possíveis dificuldades das professoras da instituição aos agrupamentos multietários. Realizou-se, portanto, o aprofundamento teórico para adensar a análise dos dados coletados, tendo como base a bibliografia brasileira e italiana traduzida em português, que trata da possibilidade das crianças de ir além da reprodução do padrão social, realizando uma reprodução interpretativa, como diz Corsaro (2002) ${ }^{1}$, e criando novas realidades, produzindo as culturas infantis e construindo conhecimentos entre elas mesmas e entre elas e as/os adultas/os.
\end{abstract}

\section{Palavras-chave:}

criança pequena, culturas infantis, relações de idade, Educação Infantil, pré-escola.

\section{Introdução}

Nota-se que as práticas adotadas pela Educação Infantil, na maioria dos casos, mostram conceitos da sociedade adultocêntrica em que vivemos. As docentes enfrentam desafios em atuar nessa etapa da educação básica e colocar em prática o educar e cuidar de crianças pequenas de forma que hajam experimentações, brincadeiras, espaço para criar, inventar e se movimentar e, além disso, de forma que seja criado um meio no qual as crianças possam conviver com seus pares, aprendendo com as diferenças entre elas e tendo prazer com isso. A pesquisa da continuidade à investigação de cunho etnográfico iniciada em 2014, aprofundando e ampliando os conhecimentos teóricos sobre as relações de idade na pré-escola, considerando que essa convivência entre diferentes compõe um dos elementoschave na construção das culturas infantis.

\section{Resultados e Discussão}

$\mathrm{Na}$ etapa inicial da pesquisa, na qual foram observados os momentos de alimentação e brincadeiras nos parques e as relações entre as crianças em um CEMEI, pude conhecer um pouco mais a respeito dos agrupamentos multietários e, juntamente com aprofundamento teórico do tema, a situação da instituição analisada. Com relação à implementação em 2004 dos agrupamentos multietários na rede municipal de Campinas descobri que encontrou dificuldades e críticas por parte da coordenação e das docentes ouvidas nesta pesquisa. Por outro lado, as manifestações das crianças tomavam a direção oposta, buscando os encontros com os de diferentes idades e nesses momentos pareciam funcionar como "uma forma de resistência infantil ao contexto. Uma espécie de transgressão à regras" (Paula, 1994, p.85) ${ }^{2}$.

\section{Conclusões}

Nesta pesquisa foi comprovado que as próprias crianças manifestam a vontade de estarem com as outras e romperem essas barreiras e limites estabelecidos pelos adultos. Prado $(2013)^{3}$ discute a respeito das manifestações das crianças na sociedade e da forma como a mesma, muitas vezes, não as leva em consideração como se apenas aquilo que 0 adulto manifestasse fosse importante. De acordo com a autora: "As crianças estão desamparadas tendo que decidir sozinhas suas certezas, suas possibilidades e fazem isso pelo inverso, pois sabem, desde muito cedo, não poderem, não conseguirem, não serem capazes, não entenderem. Isso seria imaturidade advinda da pouca idade? Elas conhecem, pela comparação entre aquilo que Ihes é dito e aquilo que observam (e a partir do que concluem), as contradições dos adultos e da sociedade". (p. 143). O referencial teórico adotado e estudado reforça a necessidade de atentar para os direitos das crianças por espaços onde possam explorar a dimensão onírica, alimentando seus imaginários por meio de práticas e experiências autenticamente infantis em oposição à absorção ou imitação de elementos prontos e impostos por uma cultura exógena e dominante.

\section{Agradecimentos}

Agradeço ao grupo GEPEDISC - linha Culturas Infantis pelo apoio. À professora orientadora da pesquisa Ana Lúcia Goulart de Faria e às leitoras Dra. Elina Macedo e Sandra Bonotto. Agradeço também à coordenadora do CEMEI Me. Maria José Ávila, assim como às educadoras e às crianças da instituição.

1 Corsaro, William. A reprodução interpretativa no brincar ao "faz-de-conta" das crianças. In: Educação, Sociedade e Cultura, n. 17, p. 113-134. Porto: Afrontamento, 2002.

2 Paula, Ercília Maria Angeli Teixeira de. Comida, Diversão e Arte?: O coletivo infantil em situação de alimentação na creche. Dissertação (Mestrado em Educação) - FE - USP, São Paulo, 1994

${ }^{3}$ Prado, Patrícia D. Relações de idade e geração na Educação Infantil: ou porque é bem mais melhor a gente ser grande. Pro-Posições, Campinas/SP, v. 24, n. 1 (43), p. 139-157, 2013. 